\title{
Anatomical Features of (Eichhornia Crassipes (Mart.) Solms) Growing in Iraq
}

\author{
${ }^{1}$ Muazaz A. AL-Hadeethi, ${ }^{1}$ Basma M. Al-Obaidi, ${ }^{1}$ Feryal K. Khalaf and ${ }^{2}$ Baraa H. Saleh \\ ${ }^{1}$ Biology Dep., Education College for Pure Sciences - Ibn Al- Haitham, Baghdad University, Iraq. \\ Corresponding author: lubni_a75@yahoo.com \\ ${ }^{2}$ Field crops Dep., College of agriculture, AL-Anbar University, Iraq.
}

\begin{abstract}
Eichhornia crassipes (Mart.) Solms or Water hyacinth is a fertile floating aquatic widespread in worldwide. The form of plants and the anatomy parts of this plant were studied. The most important feature was obvious the air chamber with intercellular spaces by amazing arrangement. As well can notice aerenchyma tissue allow the parts of plants floated on the surface of water located in the ground meristem of root, petiole and in the mesophyll of leaves also presence of two type of crystals raphides and styloid crystals was noted of various member in the plant in addition appear astrosclereids around the air chambers, to support the plant parts from the unsuitable environmental conditions such as the speed of water flow or floods or high levels of water.
\end{abstract}

Keywords: Anatomical features, Eichhornia crassipes, Water hyacinth, aquatic plants.

\section{Introduction}

Eichhornia crassipes (Mart.) Solms or water hyacinth as common names are aquatic flowering plants from the family Pontederiaceae considered native in South America and widespread in tropical and subtropical as North America,Asia, Australia,Africa and New Zealand [1].

Water hyacinth is a perennial plant and it's characterized by being have wide leaves floating on the surface of the waters and recognized as one of the most dangerous plants in many countries [2].

It is diffuse in more than 70 countries of the worldwide including Iraq, which was alerted to enter it in the mid-eighties, the sites of its spread in Iraq are the main and branch irrigation channels in Karbala, in addition to Wasit and Samarra since then some treatment ways have been taken to combat it but because of the nature of its growth and spread, the problem has returned in recent years [3 and 4].

This species was assisted by some factors to diffuse in a different environment, including the agricultural wastes as well as seeds up to 5 thousand seeds or may be transferred by migratory birds even the people have a large extent participate to diffuse it because of the bright flowers which can plant in gardens and pools [5]. Also [6] refer that the plants can be easy to move with helps the flood water by floating leaves to living in flat or ongoing water.

Water hyacinth used commercially for cleaning wastewater for a long time [7] and in recent years, [8 and 9] mention that the plant has been used to treat different wastewaters and to produce high protein for cattle food by used the pith, leaves, fiber and roots, also importantly produce the biogas by used the leaves as energy source [10].

In this paper, describe the form and anatomical parts of this plant to know the most important tissue that the plant contains also to refer the arrangement and design the cells and tissues in this amazing plant. 


\section{Material and Method}

\subsection{Collection of Plant Material}

Eichhornia crassipes was collected from the Tigris River north of Baghdad in May 2016. The plant material was identified and documented by the flora of Iraq (Fig. 1).

\subsection{Microscopic Study}

\subsubsection{Preservation the samples:}

The fresh samples of the stem are kept in formalin acetic acid (FAA) which was prepared according to [11] for 24-48 hours then preserved in $70 \%$ alcohol until the date of experiments.

\subsubsection{Study of leaves epidermis:}

Epidermis peeling was done followed by [12] where took the leaf at in the middle between the base and apex of the lamina. Samples were prepared by mechanical scraping using a razor blade, followed by washing with distilled water and were treated with $0.5 \%$ Sodium Hypochlorite for $5 \mathrm{~min}$. to remove the chlorophyll pigment, then stained in $1 \%$ safranin for 30-45 min. excess stain was washed off with distilled water, dehydrated by alcohol series (70, 95, and 100\%), finally, the epidermal samples were put on the slides and mounted by cover slides with Dextrin Plasticizer Xylene (D.P.X) .All permanent slides were examined by A. KRÜSS OPTRONIC light microscope and photographed using OMAX A35100U camera.

Determining the density of stomata and its relationship to the ordinary cells of the epidermis using stomatal index [13] as follows:

Stomatal index $=\frac{\text { number of stomata }}{\text { number of stomata }+ \text { number of ordinary epidermal cells }} \times 100$

\subsection{Fresh Sections:}

Fresh and dry plant samples of leaf and petiole were sectioned using hand sectioning method [14] as follows:

Leaf and petiole of a selected plant were cut into small pieces of a length between $(5-7) \mathrm{cm}$. segments were sectioned into thin pieces by a razor blade and were treated with $0.5 \%$ Sodium Hypochlorite for 5 min. to remove the chlorophyll pigment, then all plant samples were stained by $1 \%$ safranin for $1-2 \mathrm{~h}$. then washing with $70 \%$ alcohol to remove the excess pigment. Finally, the samples were put on the slides and mounted the cover slides by (D.P.X).

All permanent slides were examined by Olympus $\mathrm{BH} 2$ light microscope and photographed using Olympus CH3 camera.

\subsection{Powder Microscopy}

To a little quantity of finely ground plant powder taken on a microscopic slide, 1-2 drops of $0.1 \%$ phloroglucinol solution were added along with a drop of concentrated $\mathrm{HCl}$. It was mounted in glycerol and observed under the microscope. The characteristic features of the powder were noted. Analysis of powder microscopy of the leaf was done by standard procedure as [15].

\section{Result}

\subsection{Plant form}

Eichhornia crassipes or water hyacinth is a perennial and is characterized by being have wide leafy round or kidney shaped and form a rosette Leaf blades are bright green, thick and glossy, egg-shaped to round 4 - 12 $\mathrm{cm}$ width and $4-16 \mathrm{~cm}$ long and works as a sail in the wind and floating weed on the surface of the waters by spread floating parts on the surface of the water and have short bulbous and spongy petiole reached up to $30 \mathrm{~cm}$ long usually floating, Roots are fibrous, dark purple/black and hang beneath the rosette, roots as to type the long 
one rooted in the mud when the water depth and the small one is shallow and may be as rhizome. Inflorescences are a spike of $4-15 \mathrm{~cm}$ in length. It consists of $2-8$ flowers, sometimes up to 40 flowers with a bluish or white purple color, which helps to spread and multiply it as a decorative ornamental. The fruit is a capsule of a three locule have up to 50 seeds (Fig. 1).

\subsection{Leaf Epidermis}

The epidermis of the leaf is glabrous and many raphides crystals appear it, so the starch grain spread in the cells can be distinguished it by the concentric crashed hilum in the middle of grain (Fig. 2).

Stomata are paracytic type, the average size of guard cells reached to $7.5 \mu \mathrm{m} \times 3.5 \mu \mathrm{m}$ and the average size of the stomata aperture was $4.5 \mu \mathrm{m} \times 4.3 \mu \mathrm{m}$ also calculated the stomata frequency on the upper and lower epidermis reached to (2.80 and 3.33) $\mathrm{mm} 2$ respectively so the leaves are amphistomatic design (the stomata appear on the two side) (Fig. 3).

\subsection{Cross Section of Leaf:}

Measurements of cell sizes in leaves are shown in Table 2.

Blade of the leaf has a very thin layer of cuticle located on upper epidermis, followed by three layers of ordinary epidermis rectangular in form, the lower epidermis a single layer like the upper in form. The mesophyll is distinguished into three palisade layer beneath the upper epidermis and one palisade layer after the lower epidermis, the spongy layer followed the palisade layer and characterized as two type of parenchyma cells, the first one was storages parenchyma have many starch grains and raphides crystals and the second type of spongy layer were the aerenchyma tissue have air space store the air to supply it the plant cell for can float on the surface of water, the air space surrounded by thin walls of chloroplast to supply the chlorophyll for the photosynthetic process, so can featured two type of sclereids the first type are styloid sclereids also known pseudo-raphides are observed in the palisade layer and in air spaces, the styloid sclereids characterized by sharp ends and thicker than raphides crystals and the second type of sclereids are astrosclereids that's appear only in the air space (Fig. 4).

Vascular bundles are of two types, smaller and larger vascular bundles some of them are in contact with the epidermis and the others present in the leaf center, each vascular bundle is closed and collateral with xylem towards the lower epidermis side and phloem towards the upper epidermis side and covered by the bundle cup fiber, large vascular bundles are present in the leaf center and extend from one end to the other of the leaf (Fig.5).

\subsection{Cross Section of Petiole}

The epidermis of the petiole is single layered covered by cuticle layer. Under the epidermis located two layers of collenchyma cells, the ground meristem composed from aerenchyma tissue consist of astrosclereids also can observed styloid crystals, vascular bundled diffuse in the ground meristem contacted between as by the aerenchyma cells, the vascular bundles are closed and collateral also contains from xylem and phloem covered by bundle cup fiber. Some of the air space in the petiole full of air to supply the air to help petiole to float on the surface of the water and the other of air space full of by parenchyma cell hexagonal in shape bands with each other by ordinary schizogenous intercellular space storage the starch grain (Fig. 6 and 7).

\subsection{Cross Section of Root}

Cross section of root appear a thin layer of epidermis with a single cell followed by cortex layer consist of 3 layers of collenchyma under the epidermis and 4 layer of parenchyma cell with many raphides crystals, after the cortex located the pericycle consist from 4 layers of cells and inside the pericycle located the vascular bundles consisted from xylem in the outside and phloem inner from the xylem that's mean the vascular bundle type are phloem concentric or amphivasal (Fig. 8). 


\subsection{Powder Microscopy}

The dried leaf powder was brown in color and can observe remain of raphides crystal composed of calcium oxalate, many Starch grains with concentric crashed hilum, Vessel of xylem and fragments of tissue (Fig. 9).

\section{Dissection}

Eichhornia crassipes is one of the most dangerous types of aquatic plants affecting the water resources in many countries of the world and it comes in the foreground among the ten most dangerous plants in the world [16]. The plant was described in some studied as [17, 18 and 19].

The variation in form and function of the epidermis in hydrophytes plants as compared with plants growing in the land habitat showed Firstly the epidermis is not used for protective and supporting in hydrophytes but used for absorbs gases as $\mathrm{O} 2$ and $\mathrm{CO} 2$, in addition, the nutrients directly from water. In the presence, the plant can observe it owns an epidermis consists of a single layer and a very thin cuticle to assist absorption from surrounding water [20].

The most obvious anatomical characters in the Eichhornia crassipes is the existence of gas chambers usually large, full of by air, regular, hexagonal in shape and the intercellular spaces separate among them [16].

[21] Refer that the air is collected in the cavity of air chamber provided helps the plants during photosynthesis to take $\mathrm{CO} 2$ and stored $\mathrm{O} 2$ for used again in the respiration.

As well notice another kind of tissue allow the parts of plants floated on the surface of water known aerenchyma tissue located in the ground meristem of petiole and in the mesophyll of leaves [22]. Also in leaves and root the raphides crystals in addition the styloid crystals appear it in the leaves only diffuse in the cells this structure contains from calcium oxalate [23], the function of this structure may be absorb and storage forms of calcium and oxalic from the water also act as storehouse for metabolic wastes which to be toxic to the cell and set shape of air space so used as marker to classification the plants [24]. So in the petioles can notice two supporting tissues which are collenchyma layer under the epidermis and astrosclereids around the air chambers, these tissues provide the supporting and the power of carrying unsuitable environmental conditions such as the speed of water flow or floods or high levels of water [25].

Vascular bundles in the petioles developed lacuna in the xylem and many bundles diffuse in the ground meristem this provide the plant's tissue to transport more $\mathrm{O} 2, \mathrm{CO} 2$ and the nutrient this results agree with [26, 27 and 28]. So the vascular bundles types in the root are phloem concentric or amphivasal (xylem in the outside and phloem inside the xylem).

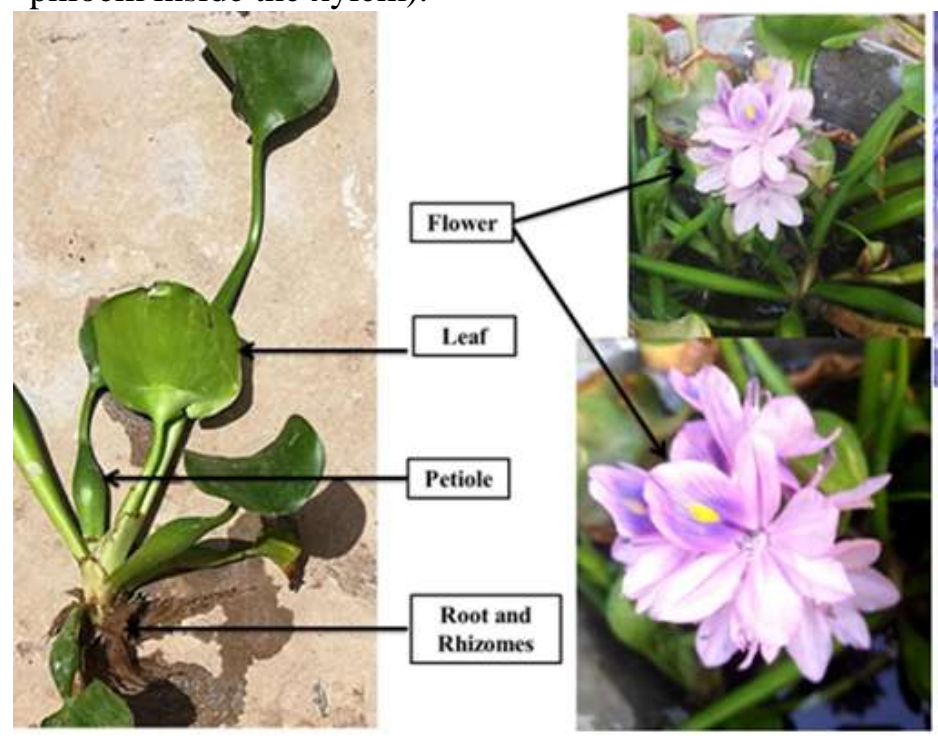

Fig. 1: Shape of Eichhornia crassipes

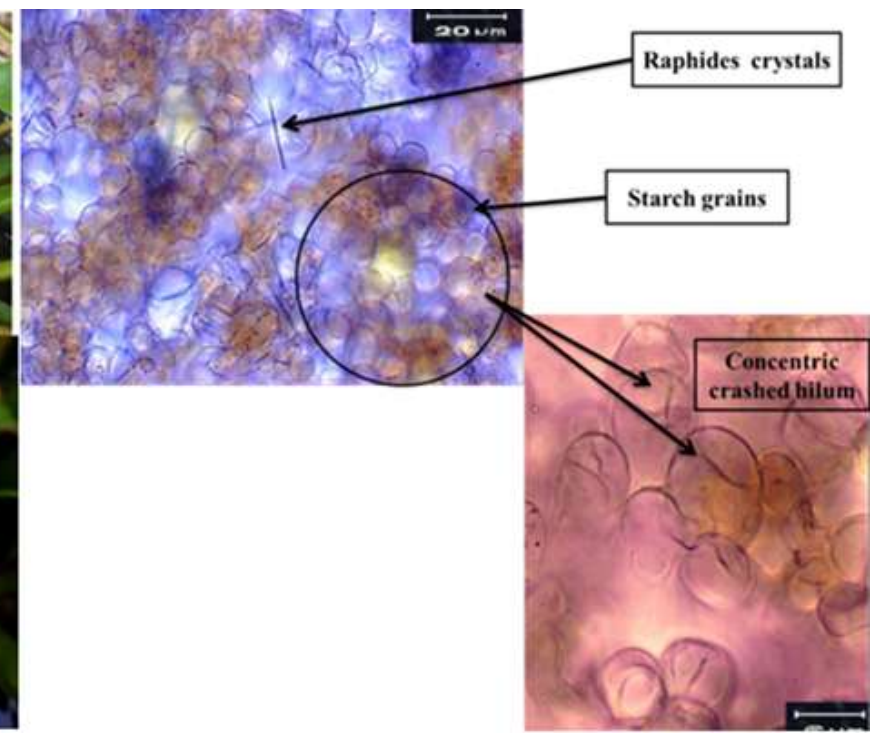

Fig. 2: Characters of Raphides crystals and starch grains in the Eichhornia crassipes . 


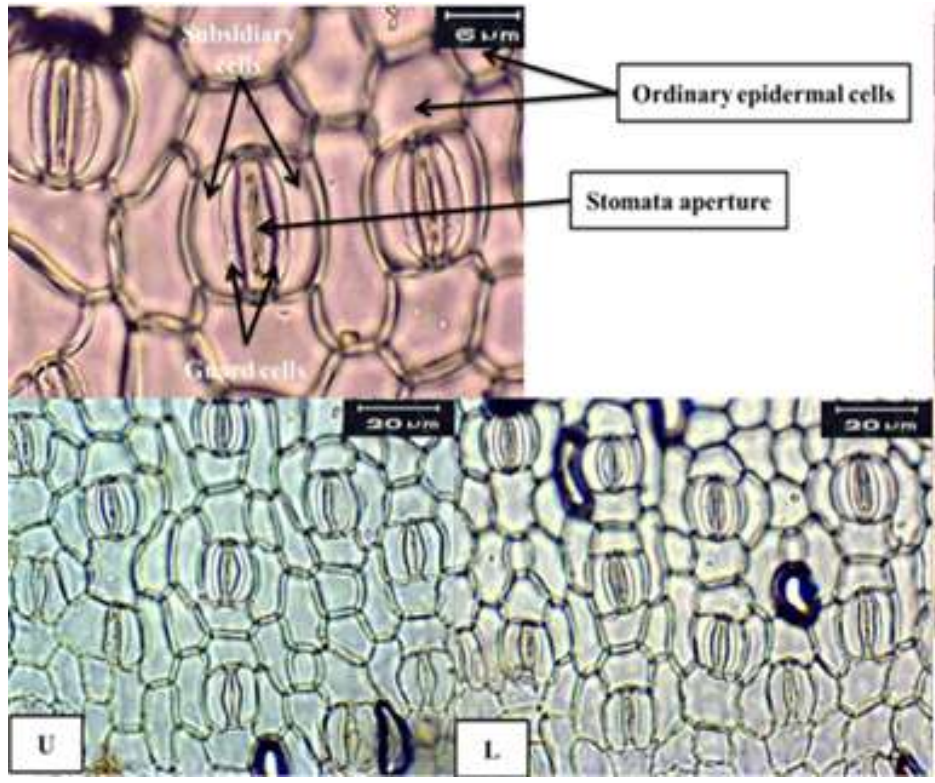

Fig. 3: Characters of Stomata shape in the Eichhornia crassipes

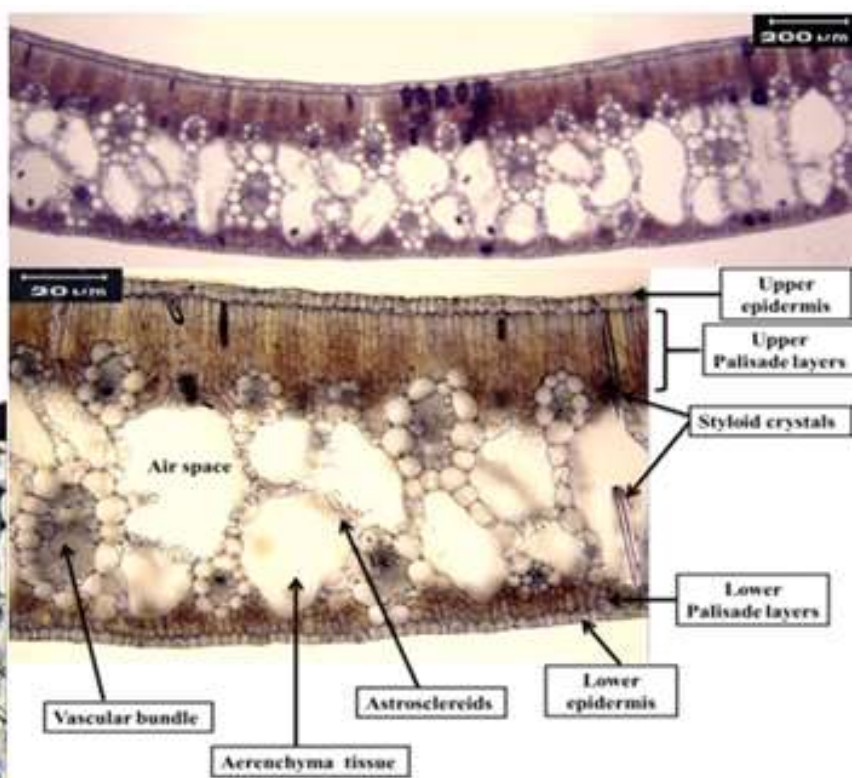

Fig. 4: Cross section of leaf in the Eichhornia crassipes.

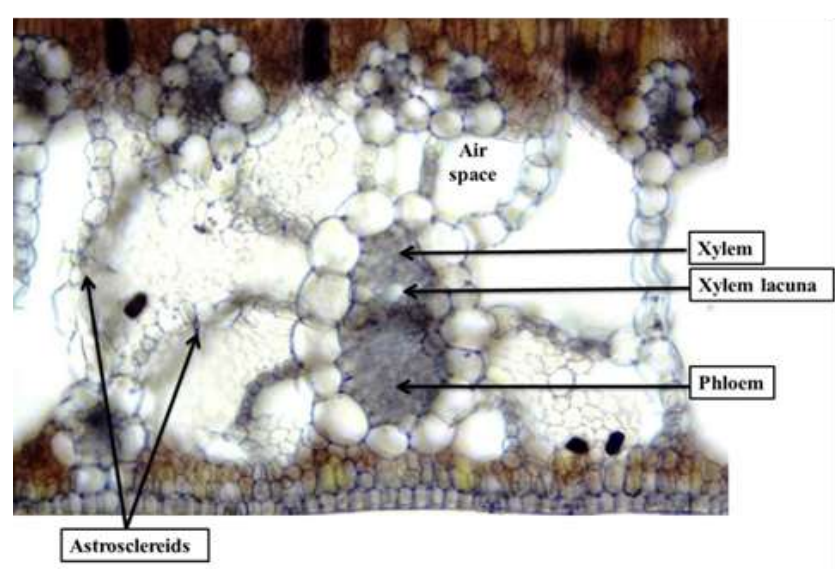

Fig. 5: cross section of leaf appear it the vascular bundles in the Eichhornia crassipes.

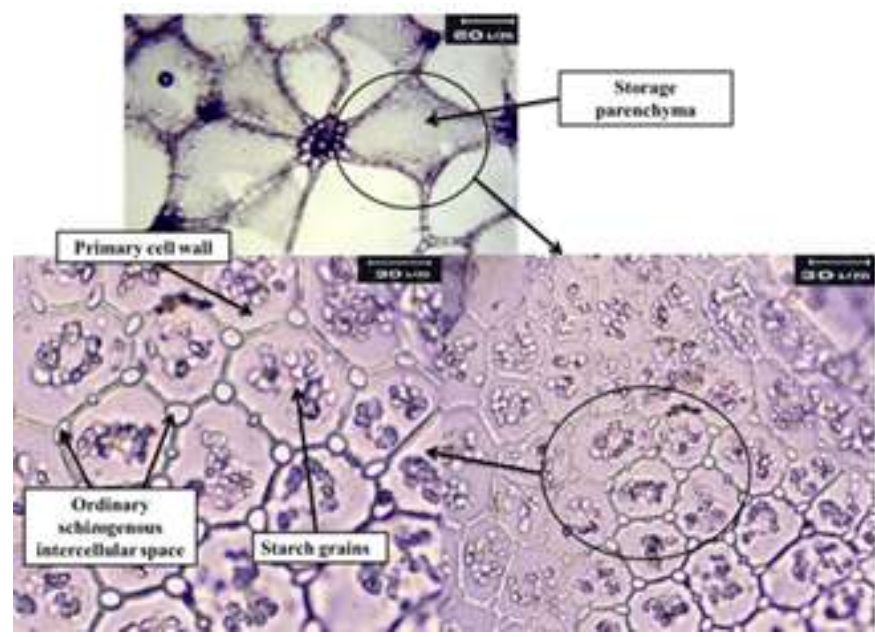

Fig 7: cross section of petiole of leaf appear it the air chamber in the Eichhornia crassipes.

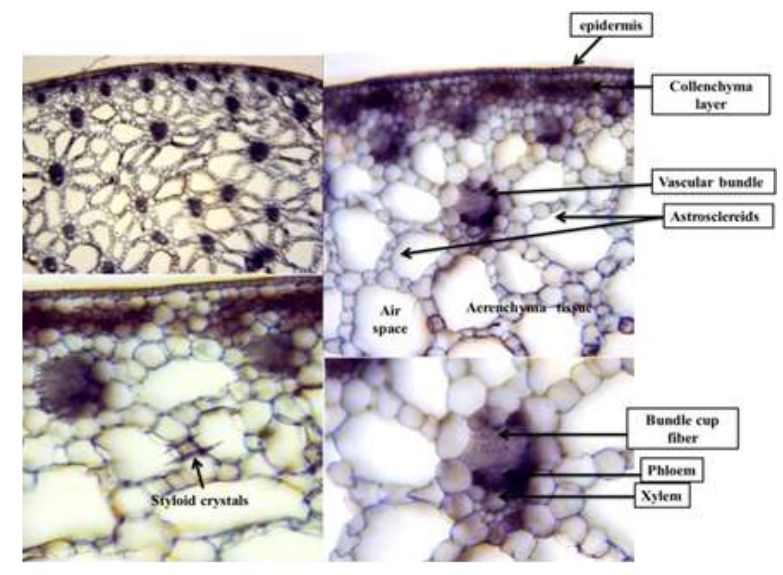

Fig 6: cross section of petiole of leaf appear it the vascular bundles in the Eichhornia crassipes.

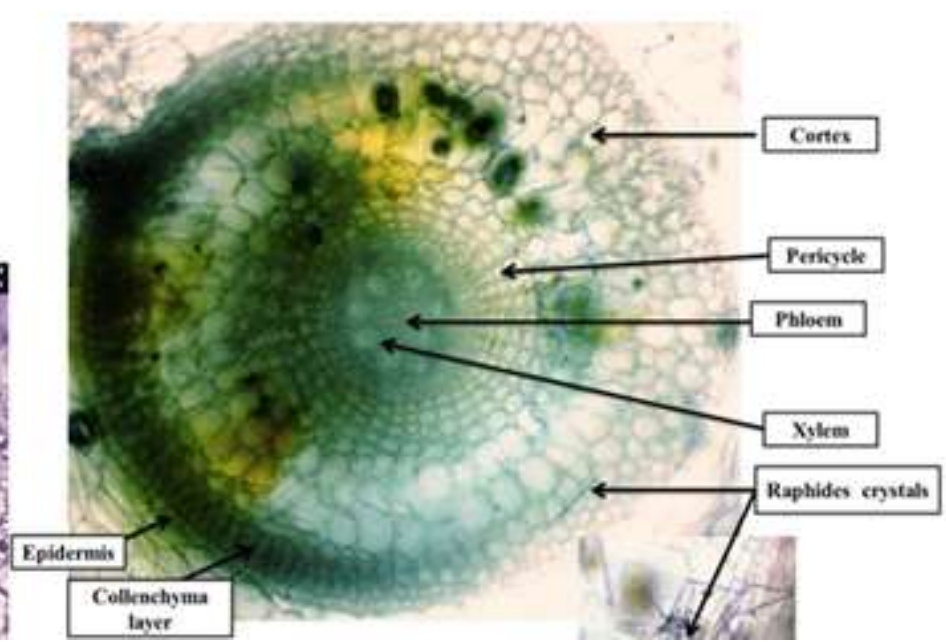

Fig. 8: cross section of root in the Eichhornia crassipes. 


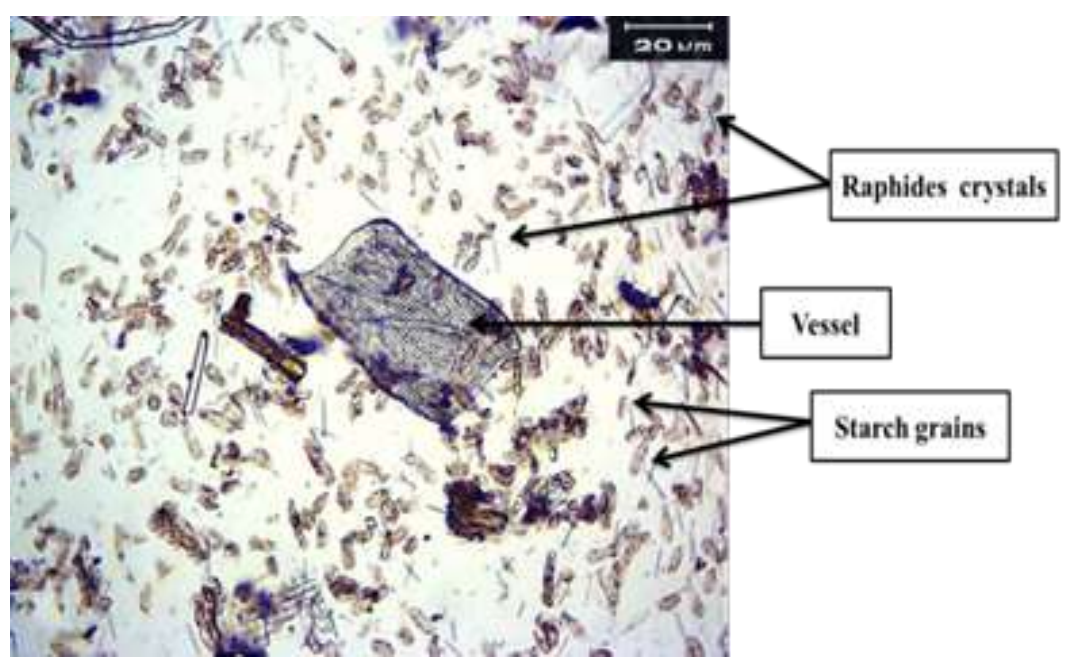

Fig. 9: Characters of fragments parts of powder microscopy in the Eichhornia crassipes

TABLE I: Characteristics of Stomatal Complex In Leaves of Eichhornia crassipes (measurement in $\mu \mathrm{m}$ ).

\begin{tabular}{|c|c|c|c|c|c|c|c|c|c|}
\hline \multicolumn{5}{|c|}{ Upper epidermis } & \multicolumn{5}{|c|}{ Lower epidermis } \\
\hline $\begin{array}{c}\text { Stomatal } \\
\text { pore }(\mu \mathrm{m})\end{array}$ & \multicolumn{2}{|c|}{ Guard cell } & $\begin{array}{c}\text { Stomatal } \\
\text { frequency }(\mathrm{mm} 2)\end{array}$ & $\begin{array}{l}\text { Stomatal } \\
\text { Index }\end{array}$ & $\begin{array}{l}\text { Stomatal } \\
\text { pore }(\mu \mathrm{m})\end{array}$ & \multicolumn{2}{|c|}{ Guard cell } & $\begin{array}{c}\text { Stomatal } \\
\text { frequency }(\mathrm{mm} 2)\end{array}$ & $\begin{array}{l}\text { Stomatal } \\
\text { Index }\end{array}$ \\
\hline \multirow[t]{2}{*}{$4.5 \times 4.3$} & $\begin{array}{c}\text { Length } \\
(\mu \mathrm{m})\end{array}$ & $\begin{array}{l}\text { Width } \\
(\mu \mathrm{m})\end{array}$ & \multirow[t]{2}{*}{2.80} & \multirow[t]{2}{*}{20.50} & \multirow[t]{2}{*}{$4.1 \times 3.9$} & $\begin{array}{l}\text { Length } \\
(\mu \mathrm{m})\end{array}$ & $\begin{array}{l}\text { Width } \\
(\mu \mathrm{m})\end{array}$ & \multirow[t]{2}{*}{3.33} & \multirow[t]{2}{*}{33.30} \\
\hline & 7.5 & 3.5 & & & & 7.0 & 3.8 & & \\
\hline
\end{tabular}

TABLE II: Characteristics of leaves of Eichhornia crassipes (measurement in $\mu \mathrm{m}$ ).

\begin{tabular}{|l|c|}
\hline Cell type & Average \\
\hline Epidermal cells & 4.5 \\
\hline Palisade cells & 6.9 \\
\hline spongy layer & 12.5 \\
\hline Air spaces & 45.5 \\
\hline Bundle sheath fiber & 5.5 \\
\hline
\end{tabular}

\section{References}

[1] Dinges R 1976 Water Hyacinth Culture for Wastewater Treatment. Texas Department of Health Resources, Austin, Texas, USA.

[2] Simpson D and Sanderson H 2002 Eichhornia crassipes. Curtis's Bot. Mag. 19 28-34.

[3] Taih MN, Habeeb MA, Abeed MH and Najem MA 2007 Eichhornia species in Iraq. Corporation of Environment and Agriculture. Karbala. Iraq. 1-7pp.

[4] Al-Wagga AHA 2012 Studying of Growth, Reproduction and Control of Eichhornia crassipes (Mart) in Nenawa Province. Ph.D. Dissertation, Coll. of Agric. and Forest.Univ. of Mosul. pp. 181.

[5] Gopal B 1987 Aquatic Plant Studies 1. Water hyacinth. Elsevier, Amsterdam.

[6] Wright AD and Purcell MF 1995 Eichhornia crassipes (Mart.) Solms-Laubach. in: R. H. Groves, R. C. H. Shepherd and R. G. Richardson. (Eds). The Biology of Australian Weeds. p. 111-121.

[7] Wolverton BC and McDonald RC 1979 The water hyacinth: from prolific pest to potential provider. Ambio. 8 1-12.

[8] Ali MM and Soltan ME 1999 Heavy metals in aquatic macrophytes, water and hydrosoils from the river Nile. Egypt. J. Union Arab. Biol. 9 99-115.

[9] Soltan ME. and Rashed MN 2003 Laboratory study on the survival of water hyacinth under several conditions of heavy metal concentrations. Adv. in Environ. Res. 7 82-91. 
[10] Agency for International Development 1976 Making Aquatic Weeds Useful, Some Perspectives for Developing Countries. National Tech. Inf. Ser. Washington D.C., No. PB161-255.

[11] Johanson AD 1940 Plant Microtechnique $.1^{\text {st }}$ ed. Mc. Graw-Hill Book Company, New York and London, 523 PP.

[12] Foster WD 1977 Freehand sectioning of bryophytes. Bull. Brit. Bryol. Soc. 2921.

[13] Stace CA 1965 The signification of the leaf epidermis in the taxonomy of the combretaceae: 1-A general Review of Tribal Genera and Specific Characters. J. Linn. Soc. (Bot.). 59 229-252.

[14] Hutchinson EP 1954 Sectioning methods for moss leaves. Bryologist 57 175-176.

[15] Hole AD, Dhanorkar VM, Gurav AM, Dhar BP and Lavekar GS 2008 Powder microscopy ad phytochemil studies of ayurvedic single drug Apamarga (Achyranthus aspera Linn.). J. D.R.A.S., 3 61-72.

[16] Nasir E and Ali SI 1977 Flora of West Pakistan. National Agriculture Research Council, Islamabad, Pakistan 114 1-4.

[17] Batanouny KH and El-Fiky AM 1975 The water hyacinth (Eichhyornia crassipes solms) in the Nile system, Egypt. Aquatic Botany 1 243-252.

[18] Téllez T, López E, Granado G, Pérez E, López R and Guzmán J 2008 The water hyacinth, Eichhornia crassipes: an invasive plant in the Guadiana River Basin (Spain). Aquatic Invasions 3 42-53.

[19] Villamagna AM and Murphy BR 2010 Ecological and socio-economic impacts of invasive water hyacinth (Eichhornia crassipes): A review. Freshwater Biology 55 282-298.

[20] Qaisar M, Ping Z, Rehan S, Ejazul S, Rashid AM and Yousaf H 2005 Anatomical studies on water hyacinth (Eichhornia crassipes (Mart.) Solms) under the influence of textile wastewater. Journal of Zhejiang University SCIENCE. 6 991-998.

[21] Thomas KT 1983 Studies on the Ecology of Aquatic Weeds in Karalla, India. Int. Conference on Water Hyacinth. Karala, India.

[22] Vesk PA, Nockold CE and Aaway WG 1999 Metal localization in water hyacinth roots from an urban wetland. Plant Cell Environ 22 149-158.

[23] Horner HT and Franceschi VR 1978 Calcium oxalate crystal formation in air space of the stem of Myriophyllium. Scanning Electron Microscopy 2 69-76.

[24] Walter WG and Khanna PN 1972 Chemistry of the aroids. I. Dieffenbachias serine, amino and picta. Economic Botany 26 364-372.

[25] Bates RP and Hentges JF 1976 Aquatic weeds-eradicate or cultivate. Econ. Bot. 30 39-50.

[26] Barnabas AD 1996 Casparian band like structures in the root hypodermis of some aquatic angiosperms. Aquatic. Bot. $55217-225$.

[27] Thomas KT 1983 Studies on the Ecology of Aquatic Weeds in Karalla, India. Int. Conference on Water Hyacinth. Karala, India.

[28] Sooknah RD and Wilkie AC 2004 Nutrient removal by floating aquatic macrophytes cultured in anaerobically digested flushed dairy manure wastewater. Ecological Engineering 22 27-42. 